\title{
Medical Dressing Treated with Honey/Chitosan Microencapsules
}

\author{
Khaled E. El-Nagar (Corresponding author) \\ Textile Metrology Lab. (TML), Chemical Metrology Division, National Institute for Standards (NIS) \\ P.O. Box: 136 Giza, Code No. 12211, Alharam, Giza, Egypt \\ Tel: 202-3383-3974Ｅ-mail: khnagare_nis@yahoo.com \\ Nashwa M. Nagy \\ Faculty of Applied Arts, Helwan University, Cairo, Egypt \\ Tel: 202-2525-1549Ｅ-mail: moustafanashwa@yahoo.com
}

Mohamed A. Elgamal

Faculty of Applied Arts, Helwan University, Cairo, Egypt

Tel: 201-22-974-0411_E-mail: elgama123@yahoo.com

Received: January 18, 2012

Accepted: February 10, 2012 Published: April 1, 2012

doi:10.5539/ijc.v4n2p79

URL: http://dx.doi.org/10.5539/ijc.v4n2p79

\begin{abstract}
Wound normally left to dry and dressing keeps infections out as well as reducing the trauma. Advanced technology is used to reduce pain and fast healing with avoiding the deformation of the injured skin. In this work previously UV/ozone irradiated medical dressing samples were treated by honey capsulated in chitosan. Treatment conditions were optimized with respect to weight; air-permeability; whiteness; yellowness and antibacterial. All treated samples showed good antimicrobial performance with sufficient air permeability and weight. The sticky nature of the honey was avoided by formation of microencapsules. Treated gauze samples showed good performance for injured rates with no inflammation.
\end{abstract}

Keywords: Microencapsulation, Honey, Chitosan, Medical textile, Medical gauze, Wound dressing

\section{Introduction}

Medical textiles are one of the most rapidly expanding sectors in the technical textile market. Medical textiles are the products \& constructions used for medical \& biological applications such as first aid, clinical and hygienic purposes (Bharat, 2007; Höfer 2003; Rajendran, 2002). Polyester medical textiles are well suited for the manufacture of vascular grafts, endovascular grafts, cardiovascular fabrics, heart valve, sewing cuffs, braided sutures, surgical meshes, umbilical tape \& any other critical applications requiring consistent properties \& reliable supply. (Hinson, 2005). Dressings with controlled permeability provide a protective barrier, prevent dry scar formation, and reduce the dermal necrosis seen in wounds that have been allowed to dry.

The burn wound healing acts like other medicated preparations as an effective antibacterial $\&$ at the same time acts like an occlusive dressing. Vaseline gauze, Sofratulle are dressings applied intra-operatively consisting of an antibiotic bulky gauze positioned by an elastic bandage (Alexander, 2003; Bishara, 2003).

The healing properties of honey have been known since ancient times (Majno, 1975; Alm, 2009). It has been used topically in the ethno-medicine of the Indian subcontinent since 2500 B.C., and also by the Egyptians, Greeks, and Romans (Ransome, 1987; Gunther, 1959; Zumla, 1989; Molan, 1992; White, 1975; Taormina et al., 2001; Allen, 1991). The most remarkable discovery was the antibacterial activity of honey (Zumla, 1989; Efem et al., 1992; Cooper, 1992; Willix et al., 1992). This antibacterial activity is related to several properties of honey (Molan, 1999; Obaseiki-Ebor, 1983; Efan, 1988; Wahdan, 1998; Postmes, 1993). In the recent years, honey has been increasingly used in modern medicine as a "potent agent" in wound healing due to its anti-bacterial and anti-inflammatory effects (Simon, 2006; Ahmed, 2003). The clinical applications of honey, particularly in the treatment of wounds, ulcers and burns are quite striking. It has been reported that honey promotes wound 
epithelization (Efem, 1993; Bergman, 1983; Efem, 1988; Subrahmanyam, 1988; Suguna, 1993), reduce inflammation (Subrahmanyam, 1998), edema (Efem, 1993; Efem, 1988; Gunther, 2010) and exudation (Efem, 1993; Efem, 1988), and accelerates synthesis of collagen and increase DNA content of the granulation tissue (Suguna, 1993; Lu et al., 2005; Ozlugedik, 2006; Koo et al., 2002; Park et al., 1998).

The aim of this work is to investigate the feasibility of using microcapsule of honey as a core shielded with antibacterial or antibiotic materials attached to/onto cotton wound dressing gauzes. To attaché these capsules onto cotton surface we will use UV/Ozone surface treatment. The treated sample with capsules will be studied for their weight, permeability water absorbance stiffness, color and tensile tension properties. The best samples for mechanical and physical properties will be used for testing the antimicrobial activity. The final samples with the best physical and mechanical performance were tested on injured rates.

\section{Experimental Work}

\subsection{Materials and Substrates}

\subsubsection{Honey Samples}

The Egyptian domestic organic honey was harvested from the National Agriculture Research Center- Ministry of Agriculture, Egypt. Honey samples were filled into glass jars after harvesting and stored at $4{ }^{\circ} \mathrm{C}$ until usage (Hyungjae et al., 2008; Turhan, 2008).

\subsubsection{Cotton Gauze}

Plain weave 1/1 sterilized organic absorbent medical cotton gauzes were purchased from the Egyptian market and characterized in the Textile Metrology lab (TML) at the National Institute for Standards- Egypt.

\subsubsection{Chemicals}

Chitosan, it is average molecular weight chitosan and of $70 \%$ deacetylation degree. It was used as shell for the capsules formulated in this study with holding the honey as a core. Chitosan was dissolved in acidified deionized water before use in this study (Krajewska, 1996).

Sodium carbonate $\left(\mathrm{Na}_{2} \mathrm{CO}_{3}\right)$, calcium chloride $\left(\mathrm{CaCl}_{2}\right)$ and acetic acid $\left(\mathrm{CH}_{3} \mathrm{COOH}\right)$ were used as grade chemicals and purchased from Elgomhoria Company - Egypt.

\subsection{Capsule Preparation (Honey as a Core and Chitosan as the Shell)}

Independent stock solutions of honey (H1 to H3) and Chitosan (C1 to C3) were prepared. Mixtures (M1 to M9) of different blending ratios (weight by weight) were prepared from the previously prepared solution(s). Tables 1-3 show the codes of the stock and mixtures in addition to the contents of both chitosan and honey in each solution (Benita, 1996; Arshady, 1999; Ranney, 1969).

\subsection{Testing and Analysis}

\subsubsection{Total Ash Contents}

Total ash content measured by incinerating honey samples in a muffle furnace at a temperature of $550{ }^{\circ} \mathrm{C}$ over night (AOAC Official Method 920.181).

\subsubsection{Measuring $\mathrm{pH}$ Value}

It was measured by a pH-meter (Model: HI 9025, manufactured by Hanna) in a solution containing $10 \mathrm{~g}$ honey in $75 \mathrm{~mL}$ of carbon dioxide free distilled water (AOAC Official Method 962.19).

\subsubsection{Free Acidity}

It is as determined by a titrimetric method as follows: the addition of $0.05 \mathrm{M} \mathrm{NaOH}$ is stopped at $\mathrm{pH} 8.5$ (free acidity), immediately a volume of $10 \mathrm{~mL} 0.05 \mathrm{M} \mathrm{NaOH}$ is added and, without delay is back titrated with $0.05 \mathrm{M}$ $\mathrm{HCl}$ to $\mathrm{pH} 8.30$ (lactonic acidity). Total acidity results are obtained by adding freeplus ${ }^{\mathrm{TM}}$ lactone acidities (AOAC Official Method 962.19).

\subsubsection{Hydroxymethylfurfural (HMF)}

It was determined after clarifying samples with Carrez reagents (I and II) and the addition of sodium bisulfite (AOAC Official Method 980.23); absorbance was determined at wavelength 284 and $336 \mathrm{~nm}$ using double beam spectrometer (Model: Lambda 35, manufactured by Perkins Elmer-USA).

\subsubsection{Mineral Analysis}

Elements including calcium $(\mathrm{Ca})$, potassium $(\mathrm{K})$, sodium $(\mathrm{Na})$, manganese $(\mathrm{Mn})$, magnesium $(\mathrm{Mg})$, iron $(\mathrm{Fe})$, cupper $(\mathrm{Cu})$, cobalt $(\mathrm{Co})$, nickel $(\mathrm{Ni})$ and zinc $(\mathrm{Zn})$ were determined by heating $10 \mathrm{~g}$ honey at $550{ }^{\circ} \mathrm{C}$ overnight, 
dissolving the resulting ash in $10 \mathrm{~mL}$ of a mixture $(1: 1)$ of $\mathrm{HCl}(1 \mathrm{M})$ and $\mathrm{HNO}_{3}(1 \mathrm{M})$, completing the volume of the solution to $50 \mathrm{~mL}$ with deionized water. Matrix modifiers were added for minerals that presented spectral interference, for instance $\mathrm{La}_{2} \mathrm{O}_{3}$ and $\mathrm{KCl}$ was added for measuring calcium and magnesium; and $\mathrm{CsCl}$ for potassium and sodium. Elemental analysis was carried out on Atomic Absorption Spectrometer (AAS) using a flame of air (Thermo-USA): acetylene and equipped with. Quantization was achieved by reference to a calibration curve and averaged over five independent measurements. Analysis of each sample was carried out in duplicate. To control the stability of the analytical signals the measurements of the standard solutions were repeated before and after the measurements of the samples. (González et al., 2000; Cemeroglu, 1992).

\subsubsection{Weight of Cotton Gauze}

Five samples were cut to specific area then weighed by Mettler Toledo of accuracy $(0.1 \mathrm{mg})$. The weight was calculated for the square meter.

\subsubsection{Color Component}

The color components as well as whiteness and yellowness indices were measured using Optimatch 3100 double beam spectrophotometer (SDL-UK).

\subsubsection{Application on Rats}

Two rats were injured with $2 \mathrm{~cm}$ burn. The time taken for complete healing was recorded for two rates. The first rat treated with the commercial antibiotic ointment while the second one treated with the developed wound dressing.

\section{Results and Discussions}

\subsection{Characterization of Cotton and Honey}

The cotton gauze samples purchased from the local market were analyzed before usage in this study to stand on the chemical, physical and mechanical interaction with the treatment studies. Table (4) shows the mechanical and physical properties of the cotton gauzes. The results in the table classify the samples into the light cotton gauzes according to EOS 4754:2005.

The honey sample was analyzed at the chemical metrology division at the National Institute for Standards (NIS-Egypt) and the results were as follow:

Honey sample that was purchased from the local market (National Agriculture Research Center, Ministry of Agriculture Egypt). Table 5 indicates the most commonly used chemical analysis for the Egyptian honey sample.

\subsection{Effect of Treatment on the Fabric Weight}

Figure 1 shows the weight gain for the treated fabric with different treatment honey/chitosan mixtures. It is clear that the effective increment was shifted to the H, H3, M2, H2, M1 and M9. This can be attributed to the increment of the solid content of these treatment mixtures with the increment of the honey content (tables 1 and 3) because honey contains about $82 \%$ dry matter (Ahmed, 2003) of its weight. In addition to the interaction between the shell of the chitosan/honey microcapsules and the activated cotton surface due to UV/ozone exposure. By comparing these values to the requirements of EOS 4757:2005 and British regulation for medicines: 1988, we can conclude that the samples C2, C3, M7, M8, M9, H1 and M6 can be used as wound dressing materials due to no press on the wounds that results in pain for the patient.

\subsection{Effect of Treatment on the Air Permeability}

Figure 2 shows the air permeability $\left(\mathrm{cm}^{3} / \mathrm{cm}^{2} / \mathrm{s}\right)$ for the treated fabric with different treatment honey/chitosan mixtures. It is clear that from figures 2 ; that the effective decrement in air permeability is shifted to the honey rich treatment mixtures. This can be attributed to the dry matter content and sticking behavior of the honey which collapse the cotton fibers altogether and block the spacing areas between yarns/fibers that block air to follow through them in addition to the high penetrability of chitosan rich mixtures. We can also refer to interactions between the shell of the chitosan/honey and the free radical on the UV/ozone treated surface. This air penetrability is very important criterion to avoid the suitable environment for anaerobic microorganisms.

\subsection{Effect of Treatment on the Antimicrobial}

Figure 4 shows the qualitative antimicrobial activity for the treated fabric with different treatment honey/chitosan mixtures. It is clear that all samples are inhibiting the growth of the microorganisms.

Anti-bacterial effect of honey is explained through osmotic effect of its high sugar content, hydrogen peroxide activity (Molan, 1992), additional non-peroxide anti-bacterial factors (Allen, 1991) and low $\mathrm{pH}$, which prevents 
growth of many organisms. Apart from all these, honey shows immune-stimulant activity by stimulating the mutagenesis of human T- and Blymphocytes and by activating the neutrophils (Abuharfeil, 1999). Prevention of infection in the fibrin tissue covering the tonsillary fossa may reduce pain via decreasing inflammation and nerve irritation. On the other hand, oral honey intake decreases the blood concentrations of prostaglandin E2, prostaglandin 2-a, and thromboxane B2, which have important functions in the acute pain mechanism and inflammatory process.

\subsection{Effect of Treatment on the Color Parameters}

The samples treated with the honey/chitosan capsules were tested for their colors. The blank sample was also measured. From the first seen we can expect the perfect microcapsule producing the less yellow color (positive $b$ component), putting in mind the chitosan aqueous media itself is a clear translucent color and the cotton gauze primary color impart to the color components. Table (6) reveals that the samples of compositions (C3, M1, C2, M9, M7 and M8) show low yellowness, which indicates that the honey is completely shielded inside the chitosan shell in the micro scale.

\subsection{Effect of Treatment on the Stiffness}

The samples treated with the honey/chitosan capsules were tested for their stiffness with respect to the bending length $(\mathrm{cm})$ using automatic stiffness tester (modified stiffness tester by TML-NIS-Egypt). Figure 5 shows the stiffness increased by increasing the honey content due to the honey constituents of wax and sugars, which impart the sticking behavior to the treated samples. On the other hand the chitosan and chitosan/honey capsules working as sliding surface to improve the softness of the fiber.

\subsection{Application of the Samples on Rats Injured with $2 \mathrm{~cm}$ Burn}

Diabetes mellitus (DM) is a contributing factor to impaired wound healing in humans. A large body of evidence indicates that the diabetic state is associated with delayed or reduced wound repair capacity. Two injured rats were treated by untreated and treated medical gauzes were investigated. Rat treated with the treated gauze showed fast healing without any inflammation than that treated with untreated medical gauze. The rate treated with treated medical gauze showed healing after 9 days with no any indication of inflammability while that was treated with untreated gauze didn't show healing up till 21 days with minor inflammation.

\section{Conclusion}

Using the microcapsules of honey as core and chitosan as a shield on the medical gauzes showed good performance in the wound healing for the diabetic rats. These treated medical gauzes have the healing and antimicrobial behaviors of honey and chitozan. The produced medical gauzes didn't affect the gas oxygen permeability to and from the surrounding environment. Developed medical cotton gauze was tested for wound healing of injured rats and the time needed for healing was nine days without any evidence of inflammation and left destroyed skin. The sticky nature of the honey was completely disappeared in the microcapsules. This research opens the door to the other researches to study the usage of these new treated medical gauzes for the human diabetes.

\section{Acknowledgment}

The Authors thank Prof. Dr. Amer Reda Mabrouk (MD surgery) from Tudor Belhars Research Institute, Ministry of scientific research for his advices and support. Authors extend their gratitude to Prof. Dr. Monira from the National Institute for Standards (NIS-Egypt) for reviewing this article.

\section{References}

Abuharfeil, N., Al-Oran R., \& Abo-Shehada M. (1999). The effect of bee honey on the proliferative activity of human B- and Lymphocytes and the activity of phagocytes. Food Agric. Immunol., 11, 169-177. http://dx.doi.org/10.1080/09540109999843

Ahmed, A. K., Hoekstra, M. J., Hage, J. J., \& Karim R. B. (2003). Honey medicated dressing: transformation of an ancient remedy into modern therapy. Ann. Plast. Surg., 50, 143-147. http://dx.doi.org/10.1097/01.SAP.0000032306.44107.C1

Al, M. L., Daniel D., Moise, A., Bobis, O., Laslo, L., \& Bogdanov S. (2009). Physico-chemical and bioactive properties of different floral origin honeys from Romania. Food Chemistry, 112, 863-867. http://dx.doi.org/10.1016/j.foodchem.2008.06.055 
Alexander, G., Nebojsa Rajacic, Mohammed K. Ebrahim, \& Ibrahim Ghoneim. (2003). Case Report MEBO and hot bitumen burns, Al-Babtain center for Burns and Plastic surgery, Ibn-Sina Hospital, Post Box No. 25427, Safat 13115, Kuwait Department of Surgery, Faculty of Medicine, Kuwait University, Jabriya, Kuwait, 14 July.

Allen, K. L., P. C. Molan, \& G. M. Reid. (1991). A Survey of the Antibacterial Activity of Some New Zealand Honeys. J. Pharm. Pharmacol., 43, 817. http://dx.doi.org/10.1111/j.2042-7158.1991.tb03186.x

Arshady, R. (1999). Microspheres, Microcapsules and Liposomes, Citrus Books, London, United Kingdom.

Benita, S. (1996). Microencapsulation: Methods and Industrial applications, Marcel Dekker Inc., New York.

Bergman, A., Yanai J., Weiss J., Bell D., \& David M. P. (1983). Acceleration of wound healing by topical application of honey. An animal model, Am. J. Surg., 145, 374-376. http://dx.doi.org/10.1016/0002-9610(83)90204-0

Bharat Book Bureau. (2007). "Introduction to Medical Textiles”, Prolog. Org-Global Press Release Distribution, Feb $13^{\text {rd }}, 1$.

Bishara S., Atiyeh, MD, FACS, Kusai A. El-Musa, MD, \& Ruwayda Dham. (2003). PHD, Scar Quality and Physiologic Barrier Function Restoration After Moist and Moist-Exposed Dressings of Partial-Thickness Wounds, Division of Plastic and Reconstructive Surgery, American University of Beirut Medical Center, Beirut, Lebanon, and Drug Research Center, Dubai, United Arab of Emirates.

Cemeroglu, B. (1992). Basic analysis methods in fruit and vegetable processing industry. Ankara, Turkey: Biltav Press.

Cooper, R. A., Molan, P. C., \& Harding, K. G. (2002). The sensitivity to honey of Gram-positive cocci of clinical significance isolated from wounds. Journal of Applied Microbiology, 93, 857-863. http://dx.doi.org/10.1046/j.1365-2672.2002.01761.x

Cooper, R., \& Molan, P. C. (1999). Wound Care, 8, 161.

Efem, S. E. (1988). Clinical observations on the wound healing properties of honey. Br. J. Surg., 75, 679-681. http://dx.doi.org/10.1002/bjs.1800750718

Efem, S. E. (1993). Recent advances in the management of Fournier's gangrene: preliminary observations. Surgery, 113, 200-204.

Efem, S. E. E., Udoh, K. T., \& Iwara, C. I. (1992). The antimicrobial spectrum of honey and its clinical significance. Infection, 20(4), 227-229. http://dx.doi.org/10.1007/BF02033065

Egyptian Standardization Organization (EOS) Numbers 2206:2005b.

Egyptian Standardization Organization (EOS) Numbers 4754:2005a.

González, A. M., Gómez Báres J. A., Garcia-Villanova R. J., Rivas Palá T., Ardunuy Albajar R., \& Sánchez J. (2000). Geographical discrimination of honeys by using mineral composition and common chemical quality parameters. Journal of the Science of Food and Agriculture, 80, 157-165. http://dx.doi.org/10.1002/(SICI)1097-0010(20000101)80:1\%3C157::AID-JSFA506\%3E3.0.CO;2-B

Gulcelik, M., Dincer, H., Sahin, D, Demir, O., Yenidogan E., \& Alagol H. Glucan. (2010). Improves Impaired Wound Healing in Diabetic Rats. Wounds, 22(1), 12-16.

Gunther R. T. (1959). Gunther -Editor, J., Goodyear -Translator. The Greek Herbal of Discords. Hafner Publishing Co., New York, USA, 1959.

Hinson, \& Hale Medical Technologies, Inc. (2005). Products \& Pricing, 100 \% fused Polyester Products, Med Tech Infused Scrubs, Sheets, Operating Room Wrapper.

Höfer, D., \& Swerev M. (2003). The future of Medical Textiles: High-tech for the Well-being of the patient. Journal of Textiles and Apparel, Technology and Management (JTATM).

Hyungjae Lee, John J. Churey, \& Randy W. Worobo. (2008). Antimicrobial activity of bacterial isolates from different floral sources of honey. International Journal of Food Microbiology, 126, 240-244. http://dx.doi.org/10.1016/j.ijfoodmicro.2008.04.030

Koo, H., Rosalen, P. L., Cury, J. A., Park, Y. K., \& Bowen, W. H. (2002). Effects of compounds found in propolis on Streptococcus mutants growth and on glucosyl transferase activity. Antimicrobial Agents and Chemotherapy, 46, 1302-1309. http://dx.doi.org/10.1128/AAC.46.5.1302-1309.2002

Krajewska, B., \& Olech, A. (1996). Pore structure of gel chitosan membranes. I. Solute diffusion measurements. 
Polym. Gels and Networks, 4, 33-43. http://dx.doi.org/10.1016/0966-7822(95)00015-1

Lu, L. C., Chen, Y. W., \& Chou, C. (2005). Antibacterial activity of propolis against Staphylococcus aureus. International Journal of Food Microbiology, 102, 213-220. http://dx.doi.org/10.1016/j.ijfoodmicro.2004.12.017

Majno, G. (1975). The Healing Hand. Man and Wound in the Ancient World. Harvard University Press, Cambridge, MA, USA, 571.

Molan, P. C. (1992a). The antibacterial activity of honey: 1. the nature of the antibacterial activity. Bee World, 73, 5-28.

Molan, P. C. (1992b). The antibacterial activity of honey: 2. Variation in the potency of the antibacterial activity. Bee World, 73, 59-76.

Molan, P. C. (1999). The role of honey in the management of wounds. J. Wound Care, 8, 415-418.

Obaseiki-Ebor, E. E., \& Afonya, T. C. A. (1983). Preliminary report on the antimicrobial activity of honey distillate. J. Pharm. Pharmacol, 35(11), 748-749. http://dx.doi.org/10.1111/j.2042-7158.1983.tb02884.x

Ozlugedik, S., Genc, S., Unal, A., Elhan, A. H., Tezer, M., \& Titiz, A. (2006). Can postoperative pains following tonsillectomy be relieved by honey? International Journal of Pediatric Otorhinola-ryngology, 70, 1929-1934. http://dx.doi.org/10.1016/j.ijporl.2006.07.001

Park, Y. K., Koo, M. H., Abreu, J. A. S., Ikegaki, M., Cury, J. A., \& Rosalen, P. L. (1998). Antimicrobial activity of propolis on oral microorganisms. Current Microbiology, 36, 24-28. http://dx.doi.org/10.1007/s002849900274

Postmes, T., Boogaard, A. E. Van den, \& Mathew Hazen. (1993). Honey for wounds, ulcers, and skin graft preservation. Lancet, 341, 756-757. http://dx.doi.org/10.1016/0140-6736(93)90527-N

Rajendran, S., \& Anand S. C. (2002). Development in Medical Textiles. Textile Progress, 10-33.

Ranney, M. W. (1969). Microencapsulation Technology, Noyes Development Corporation, Park Ridge, 6, 275.

Ransome H. R. (1987). The Sacred Bee: In Ancient Times and Folklore, Dover Publications, Mineola, NY, USA, 308.

Subrahmanyam, M. (1998). A prospective randomized clinical and histological study of superficial burn wound healing with honey and silver sulfadiazine. Burns, $24, \quad 157-161$. http://dx.doi.org/10.1016/S0305-4179(97)00113-7

Suguna, L., Chandrakasan, G., Ramamoorthy, U., \& Thomas J. K. (1993). Influence of honey on biochemical and biophysical parameters of wounds in rats. J. Clin. Biochem. Nutr., 14, 91-99. http://dx.doi.org/10.3164/jcbn.14.91

Taormina, P. J., Niemira, B. A., \& Beuchat, L. R. (2001). Inhibitory activity of honey against food borne pathogens as induenced by the presence of hydrogen peroxide and level of antioxidant power. International Journal of Food Microbiology, 69, 217-225. http://dx.doi.org/10.1016/S0168-1605(01)00505-0

Wahdan, H. A. L. (1998). Causes of the antimicrobial activity of honey. Infection, $26(1), 26-31$. http://dx.doi.org/10.1007/BF02768748

White Jr., J. W., Subers, M. H., \& Schepartz, A. I. (1963). The identification of inhibine, the antibacterial factor in honey as hydrogen peroxide and its origin in a honey glucose oxidase system. Biochemica ET Biophysica Acta, 73, 57-70. http://dx.doi.org/10.1016/0926-6569(63)90108-1

White, Jr., J. W. (1975). Composition of honey. In: Crane, E. (Ed.), Honey: a Comprehensive Survey. Crane, Russak \& Company, Inc., New York, 157-206.

Willix, D. J., Molan, P. C., \& Harfoot, C. G. (1992). A comparison of the sensitivity of wound infecting species of bacteria to the antibacterial activity of Manuka honey and other honey. Journal of Applied Bacteriology, 73, 388-394. http://dx.doi.org/10.1111/j.1365-2672.1992.tb04993.x

Zumla, A., \& Lulat, A. (1989). Honey-a remedy rediscovered. Journal of the Royal Society of Medicine, 82, 384-385. 
Table 1. Chitosan stocks formulations

\begin{tabular}{|c|c|c|c|}
\hline Stock code & Total weight (g) & Chitosan (g) & Chitosan (\%) \\
\hline C1 & 100.4265 & 0.9991 & 0.9948 \\
\hline C2 & 100.0319 & 0.2536 & 0.2535 \\
\hline C3 & 102.3170 & 0.5062 & 0.4948 \\
\hline
\end{tabular}

Table 2. Honey stock formulations

\begin{tabular}{|c|c|c|c|}
\hline Stock code & Total weight (g) & Honey (g) & Honey (\%) \\
\hline H1 & 100.0930 & 12.5101 & 24.8458 \\
\hline H2 & 100.6207 & 25.0000 & 75.1129 \\
\hline H3 & 100.1676 & 75.2388 & \\
\hline
\end{tabular}

Table 3. Formulations of chitosan and honey blends

\begin{tabular}{|c|c|c|c|c|c|}
\hline Mixture code & H3 (g) & C1 (g) & $\mathrm{C} 1+\mathrm{H} 3$ (g) & Chitosan (g) & Honey (g) \\
\hline M1 & 15.132 & 35.054 & 50.1854 & 0.349 & 11.366 \\
\hline M2 & 30.012 & 20.185 & 50.1975 & 0.201 & 22.543 \\
\hline \multirow[t]{2}{*}{ M3 } & 45.093 & 5.0159 & 50.1085 & 0.050 & 33.870 \\
\hline & H2 (g) & C3 (g) & $\mathrm{C} 3+\mathrm{H} 2(\mathrm{~g})$ & & \\
\hline M4 & 15.000 & 36.000 & 51.000 & 0.178 & 3.727 \\
\hline M5 & 30.000 & 20.500 & 50.500 & 0.101 & 7.454 \\
\hline \multirow[t]{2}{*}{ M6 } & 45.600 & 15.000 & 60.600 & 0.074 & 11.330 \\
\hline & H1 (g) & C2 (g) & $\mathrm{C} 2+\mathrm{H} 1(\mathrm{~g})$ & & \\
\hline M7 & 15.000 & 37.000 & 52.000 & 0.094 & 1.875 \\
\hline M8 & 30.000 & 21.000 & 51.000 & 0.053 & 3.750 \\
\hline M9 & 45.000 & 15.000 & 60.000 & 0.038 & 5.624 \\
\hline $\mathrm{H} 1$ & 6.243 & 0.000 & 50.000 & 0.00 & 6.243 \\
\hline $\mathrm{H} 2$ & 12.346 & 0.000 & 50.000 & 0.00 & 12.346 \\
\hline $\mathrm{H} 3$ & 37.494 & 0.000 & 50.000 & 0.00 & 37.494 \\
\hline $\mathrm{C} 1$ & 0.00 & 0.495 & 50.000 & 0.495 & 0.000 \\
\hline $\mathrm{C} 2$ & 0.00 & 0.127 & 50.000 & 0.127 & 0.000 \\
\hline $\mathrm{C} 3$ & 0.00 & 0.242 & 50.000 & 0.242 & 0.000 \\
\hline
\end{tabular}

$\mathrm{H}$ indicates Honey stock, $\mathrm{C}$ indicates chitosan stock, and $\mathrm{M}$ indicates mixtures or capsules of honey in chitosan. 
Table 4. Physical and chemical properties of cotton gauze fabric used

\begin{tabular}{|c|c|c|c|}
\hline Parameter & \multicolumn{2}{|c|}{ Results } & Uncertainty $( \pm \%)$ \\
\hline No of yarn $/ 5 \mathrm{~cm}$ & Weft: 60 & Warp: 44 & 1 \\
\hline Tensile strength (kg.f) & Weft: 13.4 & Warp: 5.7 & --- \\
\hline Weight (g/m2) & \multicolumn{2}{|c|}{41.6} & 6 \\
\hline Water soluble extract (\%) & \multicolumn{2}{|c|}{0.22} & 2.4 \\
\hline Diethylether soluble extract (\%) & \multicolumn{2}{|c|}{0.42} & 1.8 \\
\hline Ash content $(\%)$ & \multicolumn{2}{|c|}{0.48} & 2.1 \\
\hline Absorbance time (s) & \multicolumn{2}{|c|}{6.14} & 0.4 \\
\hline
\end{tabular}

Notes:

(a) Uncertainties included in these measurements were expanded to confidence level $95 \%$ by multiplying a covering factor ' $\mathrm{K}$ ' $=2$.

(b) The cotton gauze was found in compliance (light absorbency gauze) with the Egyptian standards (EOS 4754:2005 and EOS 2206: 2005).

(c) Samples were conditioned at temperature of $20 \mathrm{oC} \pm 2$ and relative humidity of $65 \% \pm 2 \%$ for 24 hours before performing any test.

Table 5. Honey chemical properties

\begin{tabular}{|l|c|}
\hline Test & Results \\
\hline pH value & 4.02 \\
\hline Total dry matter (\% w/w) & 82.90 \\
\hline Soluble solids $\left({ }^{\circ} \mathrm{Bx}\right)$ & 72.83 \\
\hline Total acidity (meq/kg) & 27.15 \\
\hline Formol number & 20.00 \\
\hline $\mathrm{Hydroxymethylfurfural} \mathrm{HMF} \mathrm{(mg/kg)}$ & 0.80 \\
\hline Heavy Element Content & 287.30 \\
\hline $\mathrm{K}(\mathrm{mg} / \mathrm{kg})$ & 20.72 \\
\hline $\mathrm{Ca}(\mathrm{mg} / \mathrm{kg})$ & 132.09 \\
\hline $\mathrm{Mg}(\mathrm{mg} / \mathrm{kg})$ & 2.45 \\
\hline $\mathrm{Mn}(\mathrm{mg} / \mathrm{kg})$ & 29.37 \\
\hline $\mathrm{Na}(\mathrm{mg} / \mathrm{kg})$ & 1006.72 \\
\hline Fe (mg/kg) & 0.002 \\
\hline $\mathrm{Zn} \mathrm{(mg/kg)}$ & \\
\hline $\mathrm{Cu}(\mathrm{mg} / \mathrm{kg})$ & \\
\hline $\mathrm{Pb}(\mathrm{mg} / \mathrm{kg})$ & \\
\hline
\end{tabular}


Table 6. Color measurement of fabric untreated (blank) and capsules treated samples

\begin{tabular}{|c|c|c|c|c|c|}
\hline Code & (L) & (a) & (b) & WI & YI \\
\hline C3 & 78.87 & 2.67 & -6.43 & 88.65 & -12.58 \\
\hline M1 & 77.24 & 2.37 & -5.00 & 78.82 & -9.51 \\
\hline M9 & 83.85 & 1.69 & -4.04 & 84.12 & -7.24 \\
\hline M7 & 81.96 & 1.86 & -4.02 & 80.83 & -7.17 \\
\hline M8 & 85.40 & 1.68 & -4.01 & 86.68 & -7.05 \\
\hline M6 & 83.72 & 1.66 & -3.79 & 82.65 & -6.70 \\
\hline H2 & 79.69 & 1.42 & -2.98 & 77.62 & -5.10 \\
\hline H1 & 81.54 & 0.82 & -2.25 & 67.96 & -3.73 \\
\hline Blank & 96.10 & -0.50 & 0.19 & 58.47 & 1.48 \\
\hline H3 & 79.72 & 0.72 & 2.13 & 44.99 & 1.70 \\
\hline M2 & 79.37 & -0.01 & 4.66 & 30.85 & 10.66 \\
\hline H & 79.97 & -0.08 & 11.04 & -1.56 & 23.67 \\
\hline H3 & 79.04 & 0.08 & 15.59 & -27.83 & 32.82 \\
\hline
\end{tabular}

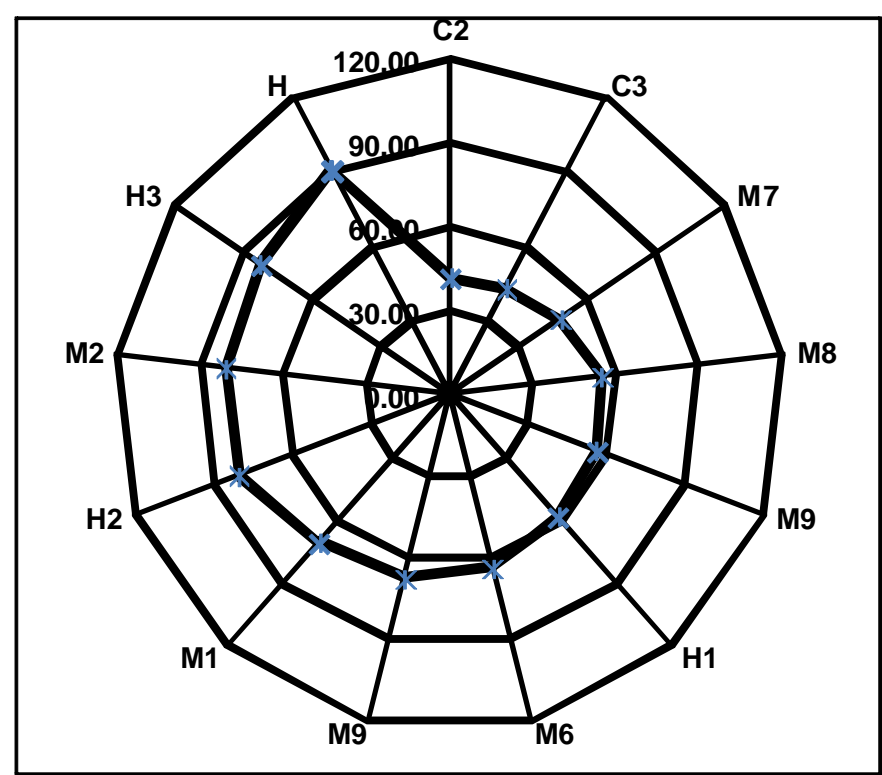

Figure 1. Effect of treatment of the UV/ozone activated surface cotton gauze with honey/chitosan capsules on their weight $\left(\mathrm{g} / \mathrm{m}^{2}\right)$ 


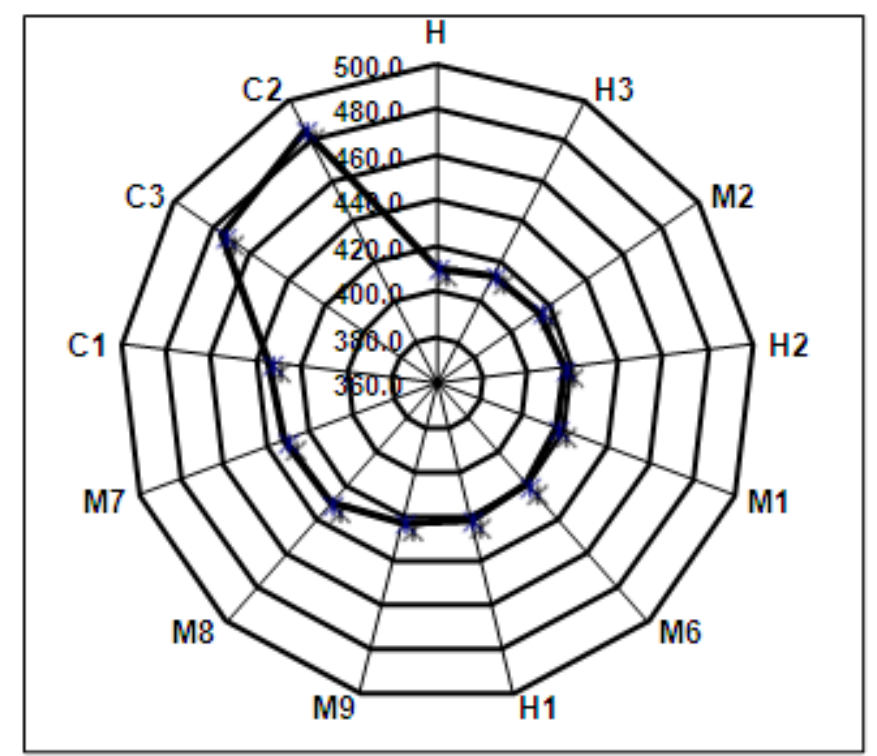

Figure 2. Effect of treatment of the UV/ozone activated surface cotton gauze with honey/chitosan capsules on their air penetrability $\left(\mathrm{cm}^{3} / \mathrm{cm}^{2} / \mathrm{s}\right)$

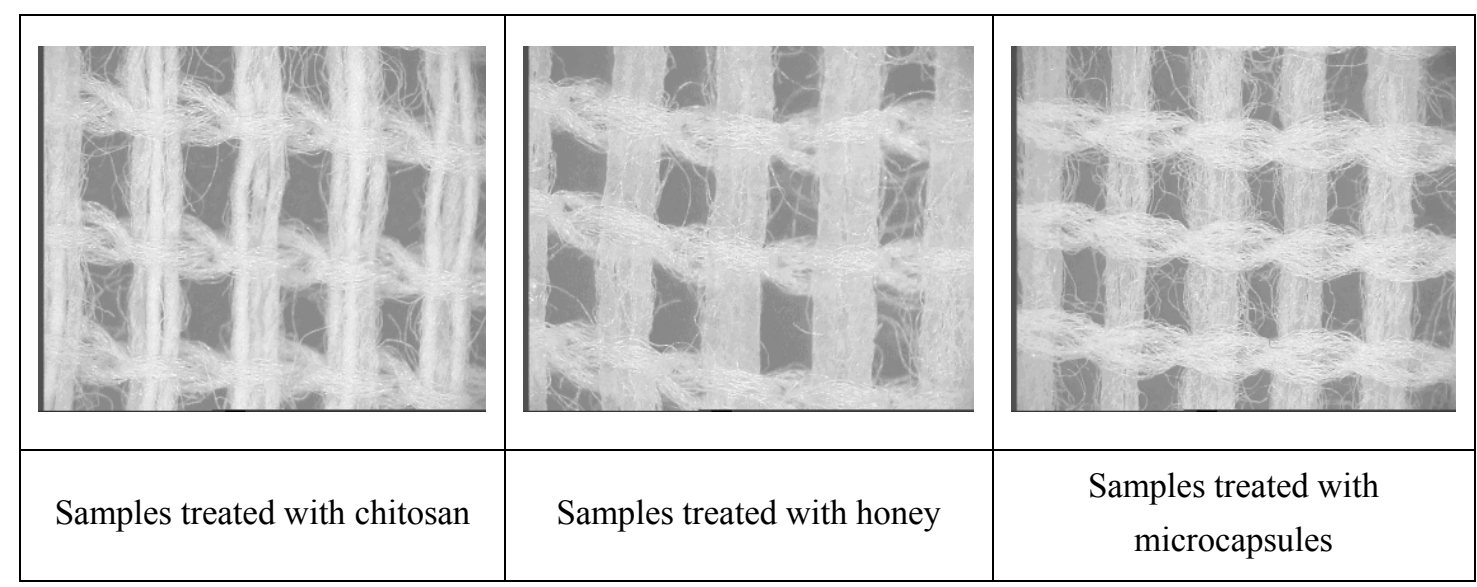

Figure 3. Optical images for the treated cotton gauzes

\begin{tabular}{|c|c|c|c|c|c|}
\hline (-ve) H3 & (-ve) C1 & (-ve) M3 & (-ve) M2 & (-ve) M1 & (-ve) C \\
\hline (-ve) H2 & (-ve) C3 & (-ve) M4 & (-ve) M5 & (-ve) M6 & (-ve) H \\
\hline (-ve) H1 & (-ve) C2 & (-ve) M9 & (-ve) M8 & (-ve) M7 & \\
\hline
\end{tabular}

Figure 4. Antimicrobial activity of the cotton gauze treated samples. $(-\mathrm{ve})$ indicates no bacterial growth; (+ve) indicates a bacterial growth 


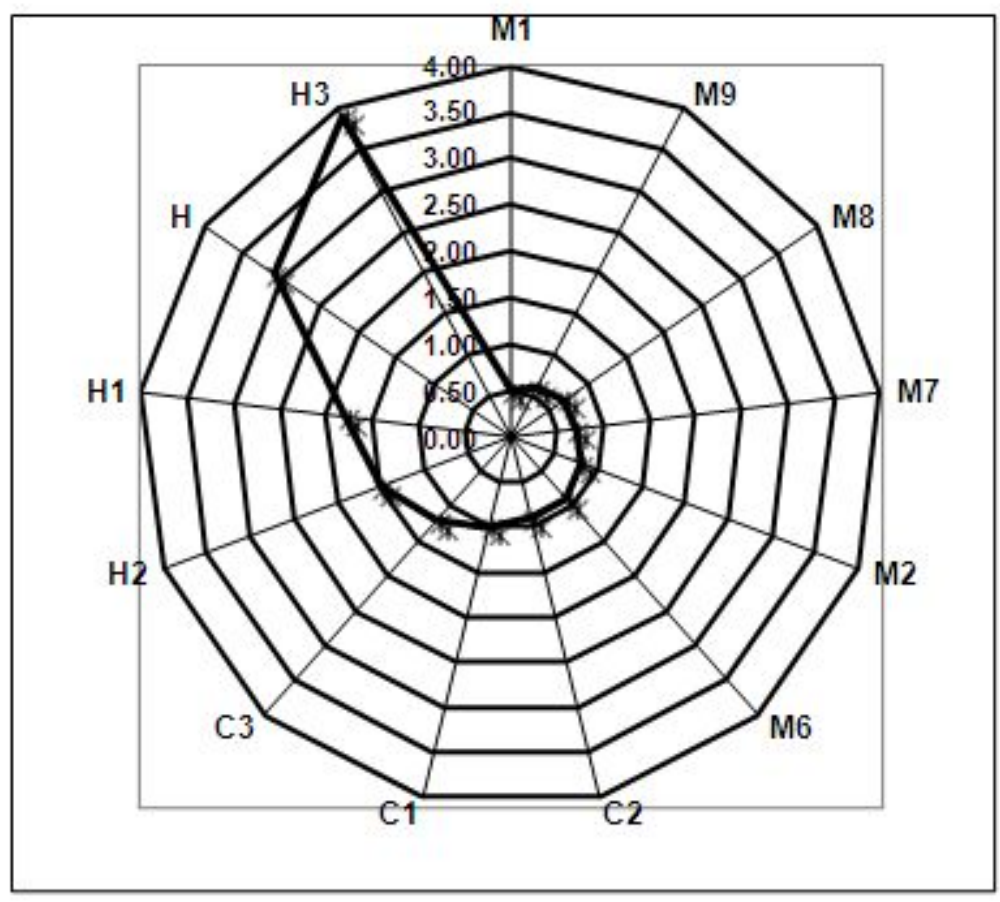

Figure 5. Effect of treatment cotton UV/ozone activated surface with microcapsule on stiffness properties (as bending length $\mathrm{cm}$ ) 